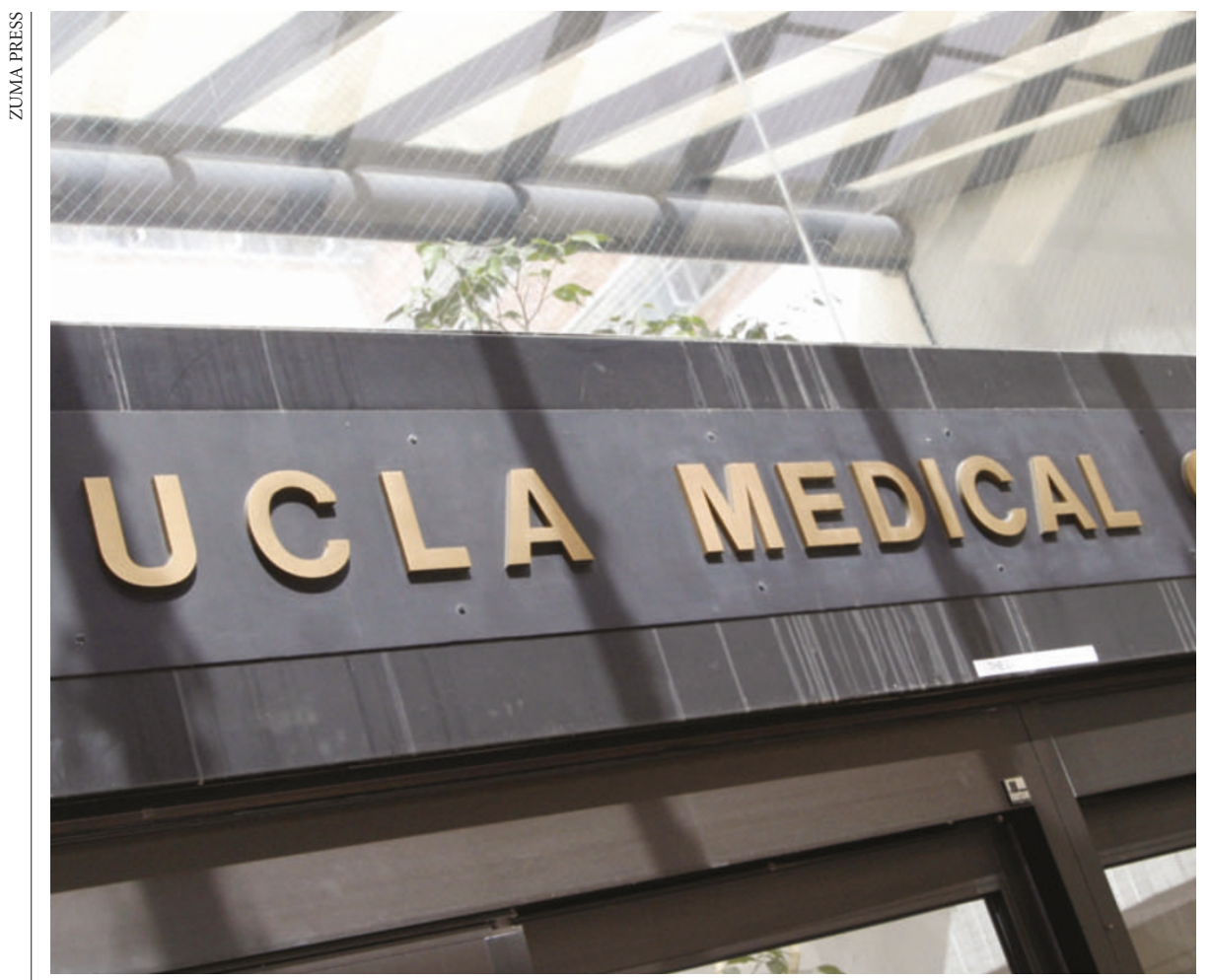

School for scandal: the University of California, Los Angeles, is no longer accepting body bequests.

\section{Two arrested for trade in body parts from donor programme}

Rex Dalton, San Diego

Allegations of an illicit trade in body parts at the University of California, Los Angeles (UCLA), have forced the institution's authorities to rethink the systems used to collect human tissue for research.

UCLA's David Geffen School of Medicine last week suspended its programme for accepting donated human bodies, after the arrests of an employee and an independent tissue broker. The pair are alleged to have participated in a scheme in which human body parts were supplied to biotechnology firms and research institutions.

The Willed Body Program, which receives annually about 175 cadavers for medical research and education, is a significant source of tissue for UCLA researchers, says urologist Thomas Rosenthal, associate vice-chancellor of the medical school. University officials say they are working out how to compensate for reduced access to human specimens.

Henry Reid, director of the programme, was arrested on 6 March on suspicion of grand theft. He is alleged to have allowed tissue broker Ernest Nelson to remove parts of nearly 500 cadavers from the university over the past six years. Invoices supplied by Reid show that he charged Nelson more than $\$ 700,000$ for the body parts.

Rosenthal says a preliminary investigation indicates that Reid was not paying the money from Nelson into UCLA bank accounts. Reid, who coincidentally was hired by UCLA in 1997 to correct problems in handling cadavers, could not be reached for comment.

Nelson, who runs Empire Anatomical Services from a storage facility in a suburb of Los Angeles, shipped specimens to what his attorney, Greg Hafif, called "accredited research institutions" and US biotechnology firms. Hafif declined to name the companies, but Mitek Worldwide, a surgical-devices company based in Norwood, Massachusetts, has acknowledged receiving tissue from Nelson. Hafif says that Nelson is innocent of wrong-doing, as he believed he was working legitimately with UCLA.

Biotechnology companies and academic institutes need body parts for medical research and for training medical students. Although it is illegal to sell human body parts in the United States, firms can make a profit by charging to cover the costs of supplying specimens. A single human body can be parcelled out for thousands of dollars.

The UCLA irregularities come after similar instances in past decades at University of California medical facilities in San Diego and Irvine. Attempts over the years to enact stronger regulatory controls at the state and federal level have been stymied by a variety of political forces, including lobbying by institutions that want ready access to tissue.
Outspoken nuclear scientist 'forced out' over polygraph row

Jonathan Knight, San Francisco

A national security expert says he was forced to resign last year because of his vocal opposition to the use of lie detectors at his nuclear weapons lab.

Alan Zelicoff, formerly a senior scientist at Sandia National Laboratories in New Mexico, last week spoke for the first time about his resignation last July. He quit following disciplinary action against him for public criticism of polygraph testing. The lab denies any link between Zelicoff's departure and his public statements.

The Department of Energy instituted routine polygraph screening for employees at all nuclear weapons laboratories in 1999 to check for leaks of classified information. Zelicoff headed the many scientists at Sandia who objected to the move.

He published opinion pieces and cited research that suggested polygraph tests might finger innocent employees rather than catching spies.

A series of disciplinary actions followed the outbursts, culminating in a week-long suspension from the lab in June 2003, according to internal memos provided by Zelicoff. When he returned, he was barred from working on the

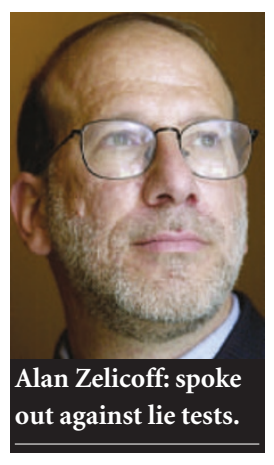
disease-surveillance software he had developed (see Nature 411, 228; 2001). The lab claimed there was a commercial conflict of interest, which he denies.

John German, a spokesman for Sandia, said that while he could not discuss Zelicoff's case, lab employees must follow procedures before speaking publicly on matters of national security. The lab memos refer to failures in this area, as well as to an alleged security infraction.

Zelicoff insists that he followed necessary procedures and says the charges in the memos are groundless. He spoke out about the affair after becoming frustrated that members of Congress to whom he had complained failed to act. Steven Aftergood, director of the Project on Government Secrecy at the Federation of American Scientists in Washington, is dismayed by Zelicoff's claims: "It tells scientists not to rock the boat." 